We thank Prof. F. Zilliken, R. C. University, Nijmegen, for a gift of thalidomide and for his advice, Miss $J$. C. Sekèt, Miss N. Kors and Mrs. W. C. Bouman-ten Das for assistance, and Mr. Boeve for taking the photographs.

During the preparation of this manuscript the publication of F. Kemper ${ }^{3}$ came to our notice. This author also observed malformations, which were, however, not further described. Growing together of the wings is not mentioned by him.

Central Rosearch Laboratories, C. A. DE Bock N. V. Philips-Duphar,

Weesp, The Netherlands.

${ }^{2}$ See, for example, Tausig, H., J. Amer. Med. Assoc., 180, 1106 (1962).

2 Rhodes, A. J., and van Rooyen, C. E., Textbook of Virology, 57 (Williams

${ }^{3}$ Arzneimittelforschung, 12, 640 (1962).

\section{A Genus of Brackish-water Oligochæta New to Britain}

During investigations into the life-cycle of Tubifex costatus (Claparède), 1863, in a brackish-water moat close to the shore of the River Mersey at Hale, Lancashiro, a tubificid genus not so far recorded from Britain was also observed ${ }^{1-4}$.

The worm was clearly recognizable as Aktedrilus monospermathecus Knöllner, 1935 , from the size and shape of the animal and its chætæ, and the single spermatheca with its dorsal pore $e^{5,6}$. The worms are very thin and reach a maximum length of $1 \mathrm{~cm}$, although some segments are missing posteriorly. There are very few chætæ in each bundle -a maximum of 5 in pre-clitellar bundles is much rarer than 2 or 3 -and all chætæ are alike. They are all bifid crotchets with the upper teeth more or less rudimentary. The detailed structure of the male efferent ducts was not observed in this material but a careful study of whole mounts revealed that the cuticular covering of the penis was sufficiently thickened to appear as a very thinwalled penis-sheath in one specimen. This was so thin that it was distorted in whole-mount preparations and its detailed shape could not be ascertained, but it seemed to be larger than its breadth at the base and to taper distally as in Tubifex templetoni Southern, 1909.

Aktedrilus monospermathecus has also been recorded from the shores of Kiel Bay and Schleswig, the River Weser at Blumenthal, Vegesack, and Bremen waterworks, the Baltic in general and the Mediterranean ${ }^{5-8}$. The salinity preferences of the species are given as $0-18 \%$ and its range from $1 \cdot 25-20 \mathrm{~S} \%$ with a preference for $2 \cdot 5-5$ $\mathrm{S} \%$ (ref. 8). The species was overlooked in earlier surveys of the habitat at Hale as it is very scarce; only 12 specimens were observed among 2,078 specimens of $T$. costatus. Its normal habitat is the interstitial space of sandy sea shores, but at Hole it was found in thin yellow clay overlying a thick blue-groy clay in a moat surrounding a small coppice. The moat was connected to the Mersey via an organically polluted stream which has recently been dredged and straightened to accommodate the tidal flow. The shore of the Mersey at the nearest point is a mass of foul, black mud and clay, and the nearest sandy shores are beyond Liverpool docks.

It is very probable that several other marine Tubificidae remain to be added to the British list; but many are very small and readily overlooked unless samples are sieved through a very fine mesh.

Since this note was prepared, another marine species has been recorded-(Thalassodrilus (Rhyacodrilus) prostatus (Knöllner), 1935-n.g. (ref. 9)) -as well as Tubifex (Limnodrilus) newaensis (Michaelsen), 1903 (ref. 4).

Department of Zoology,

University of Liverpool.

${ }^{1}$ Brinkhurst, R. O., Proc. Zool. Soc. Lond., 138, 317 (1962).

${ }^{2}$ Brinkhurst, R. O., Proc. Zool. Soc. Lond., 140, 315 (1963).

${ }^{3}$ Brinkhurst, R. O., Intern. Rev. Hydrobiol. Supp. 2 (in the press).

${ }^{4}$ Brinkhurst, R. O., Sci. Pub. Freshwater Biol. Assoc. (in the press).

- Knöllner, F. H., Zool. Jahrb., 66, 425 (1935).

${ }^{6}$ Hrabe, S., Pub. Fac. Sci. Univ. Brno, 415, 245 (1960).

'Jansson, B. O., Oikos, 13, 293 (1962).

${ }^{8}$ Bulow, Th., Kieler Meeresforsch., 13, 69 (1957).

${ }^{\circ}$ Brinkhurst, R. O., J. Mar. Biol. Assoc. (1963) (in the press).

\section{Retention of Organomercury Compounds on Dressed Grain after Washing}

FARMERs and seed merchants may occasionally have a surplus of grain dressed with organomercury fungicide when sowing is completed. Lindström ${ }^{1}$ has reported that more than 50 por cent of a dry formulation (containing: ethylmercury chloride) was washed off grain dressed in the laboratory after shaking for 10 min with water, thus showing that washing could reduce the potential hazard of such grain if used as part of a ration to feed livestock. In contrast, less than 5 per cent of a wet dressing (methylmercury dicyandiamide formulation) was removed. Consequently, the amount of fungicide retained after washing wheat and barley, dressed commercially, has been investigated: it was found to be considerable.

In our investigations, eight $2-3-\mathrm{kg}$ samples of treated wheat or barley were taken from normal large-scale dry and wet treatments; in addition, $28 \mathrm{~kg}$ of wheat was dressed with a methylmercury dicyandiamide formulation at request. An interval of at least four weeks clapsed between dressing and analysis.

$160 \mathrm{~g}$ of each sample was placed in turn in a Buchner funnel and a steady stream of cold water run over the grain for 5 min; after draining for a few minutes, each sample was divided into eight aliquots of $20 \mathrm{~g}$ and analysed by a slightly modified procedure of that recommended by the Joint Mercury Residues Panel ${ }^{2}$. As controls, I60-g samples of unwashed grain were divided into $20 \mathrm{~g}$ aliquots and analysed. The levels of mercury found are given in Table 1.

It was found in the case of one dry formulation, based on phenylmercury acetate and ethylmercury chloride, that half the dressing could be washed off, as described by Lindström. However, in the cases of the other three dry dressings examined, only 10-15 per cent was washed off. Neither the methylmercury dicyandiamide nor the phenylmercury acetate liquid formulations were readily removed. No evidence was obtained, therefore, in the

Table 1. Organomeroury Compound on Dressed Grain bFfore and after Washing with Water

\begin{tabular}{|c|c|c|c|c|c|}
\hline \multirow{2}{*}{ Organomercury compounds used in dressings } & \multirow{2}{*}{ Grain } & \multirow{2}{*}{$\begin{array}{c}\text { Level of organomercury } \\
\text { compound before, washing } \\
\text { expressed as p.p.m. } \\
\text { mercury }\end{array}$} & \multirow{2}{*}{$\begin{array}{c}\text { Level of organomercury } \\
\text { compound after washing } \\
\text { expressed as p.p.m. } \\
\text { mercury* }\end{array}$} & \multicolumn{2}{|c|}{$\begin{array}{l}\text { Organomercury compound } \\
\text { washed off }\end{array}$} \\
\hline & & & & mer.m. & $\%$ \\
\hline $\begin{array}{l}\text { Methylmercury dicyandiamide (liquid formulation) } \\
\text { Phenylmercury acetate (liquid formulation } \dagger \text { ) } \\
\text { Phenylmercury acetate } \\
\text { and ethylmercury chloride (first dry formulation) } \\
\text { Phenylmercury acetate } \\
\text { and ethylmercury chloride (second dry formulation) }\end{array}$ & $\begin{array}{l}\text { Wheat } \\
\text { Barley } \\
\text { Wheat } \\
\text { Wheat } \\
\text { Barley } \\
\text { Wheat } \\
\text { Barley }\end{array}$ & $\begin{array}{r}6 \cdot 3 \pm 0 \cdot 1 \\
10 \cdot 4 \pm 0 \cdot 1 \\
15 \cdot 7 \pm 0 \cdot 5 \\
14 \cdot 1 \pm 0 \cdot 7 \\
16 \cdot 5 \pm 0 \cdot 3 \\
21 \cdot 9 \pm 0 \cdot 4 \\
18 \cdot 3 \pm 0 \cdot 2 \\
17 \cdot 8 \pm 0 \cdot 5 \\
26 \cdot 6 \pm 0 \cdot 7\end{array}$ & $\begin{array}{r}6 \cdot 1 \pm 0 \cdot 2 \\
9 \cdot 2 \pm 0 \cdot 1 \\
15 \cdot 3 \pm 0 \cdot 7 \\
12 \cdot 2 \pm 0 \cdot 5 \\
14 \cdot 4 \pm 0 \cdot 3 \\
20 \cdot 3 \pm 0 \cdot 7 \\
17 \cdot 6 \pm 0 \cdot 2 \\
9 \cdot 4 \pm 0 \cdot 4 \\
22 \cdot 7 \pm 0 \cdot 5\end{array}$ & $\begin{array}{l}0 \cdot 2 \\
1 \cdot 2 \\
0 \cdot 4 \\
1 \cdot 9 \\
2 \cdot 1 \\
1 \cdot 6 \\
0 \cdot 7 \\
8 \cdot 4 \\
3 \cdot 9\end{array}$ & $\begin{array}{r}3 \\
12 \\
3 \\
13 \\
12 \\
7 \\
4 \\
47 \\
15\end{array}$ \\
\hline
\end{tabular}

* Mean $\pm S . E$. of mean. † Mixed with a chlorinated hydrocarbon insecticide dressing. 